\title{
Gesta de lobos de Tomás Harris
}

Naín Nómez

Universidad de Santiago. Chile

T ace ya 28 años y a propósito de la publicación de Crónicas maravillode Santiago (1997), escribí una nota en el diario La Época titulada "Por una épica de la marginalidad. La poesía de Tomás Harris”. Allí ya había intentado "pergeñar" como diría Rojo, algunas de las características que se han reiterado y ratificado en el mejor sentido de estas palabras, en la producción poética de Harris que ya abarca una veintena de libros. Desde Zonas de peligro de 1985 hasta el libro que aquí nos ocupa, la producción de Harris, como él mismo ha señalado, mitifica, re-contextualiza, miente y edita, asociaciones arbitrarias que machacan una y otra vez una serie de tópicos, entre los cuales, el amor, el suicidio, el absurdo, la muerte y el simulacro de la vida, afloran en un ritornello acuciante y obsesivo, como una espiral en expansión hacia lo infinito.

Grínor Rojo ya llamaba la atención en 1996, a propósito de la segunda edición de Cipango, que en la poesía de Harris primaba una especie de fraccionamiento de la experiencia del poeta, que relevaba una condición de circularidad entre el viaje y la inmovilidad, una especie de circularidad o de retorno hacia el mismo sitio en que prima la imagen del "último viaje" (como se titula el libro de 1987) y la metáfora de la muerte que se reitera una y otra vez. Si en ese momento, el sujeto colonizador se asemejaba al sujeto dictatorial y el periplo del viajero estaba aun conformado por las zonas de peligro y la circunstancia política, Cipango representaría un quiebre en que las epifanías del viajero se hacen cada vez más esperpénticas y la distorsión metafórica remueve la realidad hacia un ámbito cada vez más onírico, fantasioso, serial y libertario. Lentamente en este ensanchamiento del mundo de Harris, la crónica maravillosa se va transformando 
en orfandad, intemperie, deformación de lo visto, un contratexto en que lo verdadero y lo falso son indistinguibles y en que la realidad y la fantasía conviven desplazadas hacia una épica irrisoria, degradada y marginalizada, que funciona solo en el exceso o el simulacro.

La profusión de citas, intertextualidades, referencias e interpelaciones es enorme, no sólo en relación a la cultura occidental y oriental sino también en relación a espacios, personajes, situaciones, lenguajes o lugares comunes de la realidad cotidiana, incluyendo aquellas referencias a las obras anteriores del autor. Así es como especialmente los referentes literarios y cinematográficos que denotaban los antecedentes y referencias estéticas y escriturales de los poemas, se repiten y se ensanchan de libro en libro hasta constituir un código experiencial de lecturas e intercalaciones con sus propias claves y lecturas diferentes, casi imposibles de abarcar incluso para un lector atento. A los nombres esenciales de Rimbaud, Baudelaire, Poe, Lautréamont, Eliot, Bataille, Genet, Lowry o Ginsberg, se intercalan luego el cine y la novela negra, el Diario de Colón, los discursos del Descubrimiento, las Indias, Stoker, Blake, Coleridge, Whitman, Kafka, Fritz Lang, etc. etc.

Entre Zonas de peligro de 1985 hasta Cipango de 1992/1996, lo que tenemos es un gran escenario que se expande desde la utopía del viaje a la antiutopía del imposible retorno y donde las ciudades y los personajes (poemas-libro, poemas narraciones, poemas mitos, poemas crónicas, poemas epopeyas, etc.) se repiten, se hacen seriales, entran en un montaje interminable donde toda realidad se desfonda y espejea, desde una escritura neobarroca con incrustaciones continentales y universales. Entre Crónicas maravillosas de 1997 y el libro que nos convoca Gesta de lobos, se genera un ciclo distinto dentro de la continuidad de la cual ya hablamos. Como señalaba el mismo autor en su "Nota aclaratoria" de las Crónicas, al prescindir del lector las "asociaciones arbitrarias y fantásticas" se alejaron cada vez de la "realidad", expandiendo el universo de la escritura hasta llevarla a los límites del absurdo, lo onírico o la irracionalidad de un mundo, donde prima el delirio fantasioso y la crónica de lo maravilloso negativo y en donde personajes y espacios surgen de una historia de degradación monstruosa. Esta expansión casi patológica y aberrante del universo del sujeto de la escritura, en que la unidad se sostiene en base al fragmento como cita el autor en sus primeros textos, o donde cambian los significantes pero se mantienen los significados al decir de Rojo o el relato se hace un anti-relato 
y la experiencia no sirve para que el viaje culmine en un retorno a su origen, como indica Cristián Gómez; llega a convertirse en una "gesta de lobos" antiépica, degradada y antimoderna, donde el sujeto delirante desliza un discurso contestatario al proceso burgués moderno, enraizándose con el lado B de la modernidad y finalmente, por lo tanto, agarrándose de nuevo a la vieja proyección de las vanguardias (de un modo distinto, claro) para desnudar el optimismo progresista de esta modernidad.

Desde ese no-lugar o vacío de lugar o lugar "entre" dos mundos, es decir, desde un movimiento cuyo destino es el vacío o el desfondamiento de toda realidad, se despliegan los mundos de Lobo (2015) y Gesta de lobos (2019). Insisto: hay continuidad y diferencia; ruptura y expansión. Igual lo que intuyo aquí es la sobre-interpretación de un simulacro, que es la relación del texto poético con la realidad mentada. Pero esa expansión de la que escribíamos antes, se hace retórica a través de un sinnúmero de epígrafes e intertextualidades que adensan y condensan lo que se dice, lo que se quiere decir y lo que no se dice, pero se vislumbra en las marginalias de la obra como producto inacabado. Así, las dedicatorias a Teresa en ambos poemarios, el pórtico de alusiones al otro/a lobo y cuerva de Pizarnik, Hughes y el Lector Licántropo del 2015 con su merodeo aberrante, tienen su equivalencia en Cioran y Panero y el aullido del lobo bajo la sombra de Ginsberg, en el poemario del 2019, donde las identidades amorosas y odiosas se subsumen y se superponen. Hablo de cosas que no existen, pero rumoreo y atisbo en estos poemarios algunas hebras que se escapan aunque nunca del todo. Ahora el ensanche se ha hecho inconmensurable y las intertextuales infinitas: Keats, Whitman, Odiseo, Miles, Tinto Brass, Bacon, Baudrillard, Marlowe, Otto Dix, Tiresias, Nerval, Cranach, Tarantino, Jarmuch, Walter Raleigh, Paracelso, Grass, Schlondorf, Mistral, Bowie, Block de nuevo, Ewaiponona, etc. etc.

Convertirse en Lobo y hablar desde Lobo aparecen como la irrupción de lo otro, de la alteridad, del exceso, enfrentado a lo que el establecimiento de la cultura ha sacralizado, normalizado, limitado y encerrado como la idolatría y el fetichismo de la razón occidental. Frente a los grandes inquisidores de la historia y los cazadores de Deseos de todos los tiempos, se produce "la mecánica de la vendetta" que nos devuelve "el Aullido de Ginsberg...el canto al Yo de Whitman/ y los tambores negros sudacas y mapuches" (15). El exceso de melancolía que altera la mente y que al decir de Goya produce 
monstruos, convierte esta gesta en pura gestualidad, una parodia de los valores de una academia anquilosada, que se entroniza en el espejismo de su propia historiografía realista y espúrea. De este modo, Lobo es, al mismo tiempo, una figura épica-trágica-cómica, por un lado, neorromántica, por otro, y esperpéntica-gore en un tercer aspecto. Pero sobre todo, Lobo es la figura con mayúsculas de toda las contradictorias identidades de los simulacros históricos que pueblan nuestra mente, nuestros libros, nuestras sacralizaciones, nuestros fetiches y estereotipos, nuestra navegación hacia un futuro donde se transfiguran dominadores y dominados, colonizadores y colonizados, primero, segundo y tercer mundo, continentes e islotes, individuos y colectivos, todos transfigurados en un movimiento de roles cambiantes, espejismos del poder transitorio simbolizado en ese largo aullido lobuno: de dolor, de cólera, de dominio, de represión, en suma: de impotencia y angustia. Pero es también junto con Loba, una superposición de todas las figuras que recorren la escenografía poética hacia atrás de todos los libros del poeta, como una suerte de mosaico, tejido o tapiz inacabado que simula un desfondamiento interminable de toda la cultura terremoteada por la virtualidad de lo que creemos la realidad actual. Así es, como la ironía atraviesa la descripción de las nuevas formas de vivir y sentir congeladas por el fin de la experiencia directa de una realidad cada vez más huidiza e inasible, donde el espectáculo diluye los límites de los sentidos y lo real se desfonda hasta el infinito hasta solo saber "de donde no venimos, quiénes no somos y adónde no vamos" (166). En este vórtice de signos esbozado en Gesta de lobos, es la propia cultura occidental la que se transforma en un montaje de imágenes oníricas que se superponen unas a otras entre códices apócrifos, lecturas intervenidas, símbolos atrofiados o desconstruidos, collages de tradiciones descontextualizadas, mitologías y alegorías sacadas de su fuente, mezcla de personas y personajes históricos y fabulosos. Todos desplazados por la figura irreverente del Lobo maldito, pornográfico, blasfemo y delirante, vagando por el vacío que deja la escritura y que reitera su figura, para llenar un hueco que solo el Deseo puede llenar y que en los poemas se enuncia a través de la permanente reiteración, el paralelismo o el golpeteo vacío del silencio en la escritura: "nada sobre nada" (p. 40) o "entre la nada y la nada" (167). 